\title{
Fight against Organized Crime as One of the Fundamental Conditions for the Integration in the European Union. Albanian Case
}

\author{
Vilma Spahiu, PhD.Cand. \\ Faculty of Social Sciences \& Education, European University of Tirana \\ vspahiu@uet.edu.al
}

\begin{abstract}
The Integration of Albania in the European Union Structures remains one of the most important challenges of the Albanian government, since the post-communist period. To become a member of these structures with full rights, the Albanian government must fulfil some conditions and criteria. The main purpose of this paper relates to the analysis of the war against organized crime, as one of the fundamental conditions for the European Integration. The war against organized crime has been chosen as the most important focus because the defined criteria in this matter, regardless the efforts to improve the situation, have not yet given the desired results. Furthermore, it is important to emphasize the fact that lately the representatives of European Union increasingly are underlying in their statements that Albanian governments must document reliable data, regarding the war against organized crime, and they must document sustainability in this direction and give concrete results, because still in the security sector the proper objectives have not been reached. The real issue is not related with the missing of a national strategy in the war against the organized crime, but with the effective implementation and application of this strategy.
\end{abstract}

Keywords: Organized Crime, Security, European Integration

\section{INTRODUCTION}

The world we are living in is facing many challenges these days, challenges that require a maximal engagement from all the countries in the world, in order that they can fulfil their primary target, the security and the wellness of their citizens. The threat and the challenges that we are facing relate with environmental issues, spread of mass destruction weapons, wars and ethnic conflicts in developing countries, organised crime (including all its dimensions), terrorism etc.

In the point of view of European Union, the enlargement through the membership of other countries, from one side it has been viewed as an opportunity to increase the common security and the cope with these challenges or threats, but on the other side, the acceptance and the integration of these countries brings the European Union closer to these problematic areas. Due to listed reasons the European Union has been showed willing to help the countries that aspire the solidifying of their institutions, economic development and the implementation of European Common Protection strategies in the field of Security.

Regardless the achievements and improvements made in many respects or certain areas, the Albanian society and politics still has much work to do.

Concerning the national Security, it can be defined as "the ability to face with external aggression and to resist against it" (Lucian, 1989: 5). "Security and insecurity relate to internal and external threats, which weaken state structures (such as the territorial ones as well as those institutional) and governmental regimes". (Ayoob, 1995: 9).

One of its threats relates to one of the most widespread phenomena or occurrence of today's world, organized crime. According to the Council of Europe, with organized crime we understand "Hidden activities made by organized groups of three or more individuals, for a long-term period with the aim to commit serious crimes, through joint action by using intimidation, violence, corruption or other means in order to directly or indirectly assure financial profit or any other kind of profit". (Council of Europe: 6).

This paper addresses two fundamental issues. The first one concerns with the importance of regional cooperation. The second ones relates to the identification of the elements and factors that prevent the achievement of concrete results in the fight against organized crime. Repeatedly from the senior executives and EU forums has been emphasized that "Albania seriously risks the membership at the European Unison structures, not because of the lack of a comprehensive national strategy against organized crime, but from the lack of effective feasibility and applicability of this strategy". 
In theoretical terms the paper is based on the Copenhagen School, security process. In order to reach the security process, two important stages need to be passed. The first stage concerns the identification of the issue as an existential threat, while the second stage relates to the use of a discourse of political elite with the aim to convince the audience about the importance of taking immediate precautions. In our case, the fight against organized crime is not being considered as a problem and priority that concerns only the Albanian elite, for reaching the objectives related to the membership of Albania at the European Unison, either as the increase of national security level as a fundamental obligation of the state towards their citizens. The fight against organized crime is now a problem that concerns also the Albanian society. Increasingly, the Albanian society is becoming aware for the high level of their insecurity, both in individual and community extent, which arises from the different criminal activities. Although, it is still early to talk about a full-scale awareness of our society, we have to mention that there is in increasing pressure against the government, compared to past years.

\section{Security in Western Balkan Countries}

Western Balkan countries have been seen from European Union members as very problematic, mostly related to the lack of strong institutions, fragile economic, the inability to control their borders from the penetration of criminal activities and the malfunction of the democracy.These countries, because of the frailty that they represent, are more vulnerable to different criminal activities. As to European Continent, we can say that over the years has suffered an increase of the organized crime, especially after the $90 \mathrm{~s}$. Many of the ex-communist countries, after the $90 \mathrm{~s}$, faced with the criminality in a large scale. They had to confront with criminal groups whom conducted activities like the trafficking in narcotic drugs, the trafficking of human being (for sexual exploitation, illegal emigration, etc) the trafficking of weapons, by converting them in leading furnisher of these traffics for Western European countries. As a consequence it has been created an internal insecurity for these countries that also has affected the European Union and its countries, turning it into a very problematic issue. The regional collaboration, in matters that concerns the borders security and their management, it has been seen as necessary preliminary condition in the road to integration of these countries in the European Union, minding the fact that EU was build under the principle of collaboration. Anyhow, the main responsibility belongs to the Western Balkan countries, because EU is responsible only for counseling, their assistance and their help by providing them the European model of Borders Management and Protection.

\section{Albania in the fight against organized crime}

The fight against organized crime constitutes one of the main priorities of the Albanian state's security agenda. Nowadays, Albania is faced with internal and external threats. As far as it concerns domestic policy, Albania faces challenges related to organized crime, illegal trafficking (drugs, weapons as well as human trafficking), natural disasters and terrorism. As far as it concerns foreign policy, Albania is faced with threats related to transnational crime and terrorism, proliferation of weapons of mass destruction, regional conflicts, etc. However, it should be emphasized that Albania shares all the responsibility with regard to all these concerns with its close allies: the European Union, the United States of America, its neighbouring countries as well as other democratic countries with whom Albania shares the same democratic values.

A retrospective on Albania's policy is necessary in order to understand how different Albanian governments in the past years have operated in order to fight organized crime and thus maintain and enhance the state's security. Great emphasis has been placed on regional-cooperation, since this has been seen as an effective way of preventing criminal activities and, thus, as a necessity for enhancing Albania's security policies. Regional co-operation took place in two forms: There were cases of 1) bilateral co-operation and there were cases of 2) multilateral co-operation as well.

To date, the basic document on fight against organized crime has been the "Intersectoral strategy on Fight against Organized Crime, Trafficking and Terrorism" approved by the Council of Ministers of the Republic of Albania in August 2008. It is worth noting that the objectives set in this document as well as the commitments undertaken so far have been in accordance with the obligations deriving from the Stabilization and Association Agreement between the European Union and the Republic of Albania. The strategy documented in this basic agreement concludes that the duties and responsibilities are to be divided between different institutions in Albania, while simultaneously serving the same goal, i.e. achieving positive results in the fight against criminal activities (Intersectoral Strategy on Fight against Organized Crime, Trafficking and Terrorism, 2008: 12-13). 
Yet, despite the division of the responsibilities and duties between the different institutions, and even though the main tasks have already been clearly determined, the required necessary level of cooperation and coordination between the relevant institutions charged with the fight against criminal activities has not been achieved. The current Albanian legal framework on the fight against organized crime is not of concern. It rather seems that Albania in fact does have a strong legal framework. However, the main problem remains the rather law and poor level of law enforcement, which has evoked a "climate of distrust" that affects the attitudes of the citizens towards the state and its institutions. In order to understand the reason why a large number of representatives of the European Union in their statements have described Albania's current situation with regard to organized crime as a non-tolerable one, while simultaneously demanding concrete and reliable data on the struggles of the Albanian government against organized crime, it is necessary to understand which objectives have so far been achieved based on this Intersectoral Strategy and which have not been achieved yet. A strategy includes short-term, medium-term as well as long-term goals. An analysis of the strategy shows that while some of the short-term and medium-term objectives have already been achieved, the long-term ones have not been achieved yet. The long-term goal of the strategy consists in "developing a society without threats from organized crime, a society at peace and working to continuously improve the quality of life of its citizens, thus projecting an image of a peaceful country with high security standards" (Intersectoral Strategy on Fight against Organized Crime, Trafficking and Terrorism, 2008: 22). The main goal of the Strategy was that by the end of 2013, the criminal groups operating in Albania would be identified and destroyed. Thus, criminal activity would be minimized to such a point that organized crime would not give reason for concern in the community anymore. Moreover, there would be high levels of security and law enforcement as well as a high level of respect for human rights. Albania's failure with regard to this long-term goal, which is the backbone of the Intersectoral Strategy, questions the country's right to full membership in the European Union.

\section{Conclusions \& Recommendations}

The fight against Organized Crime represents one of the most key conditions for the integration of Albania in the European Union. The issue with Albania is not about the lack of a concrete strategy against the Organized Crime, but with the lack of reliable documents that can prove the achieved results so far. The cause for this is not the dearth of a strong legal base, neither the lack of definition of the objectives and responsibilities of respective institutions, rather than the non-realization of the objectives of the responsible institutions and authorities for this process, and continuing with a low level of collaboration and coordination between them. Although the strategy does exist, in order to make it work and fulfil all its aims and objectives, we would need strong institutions, the functioning of the rule of law, a stable economical development, and all these can be reached by a good governance and the common political will.

In these conditions it becomes necessary not only the maximal commitment of all the state institutions but also the full awareness of Albanian society. In order to fight the high level of corruption and criminality in Albania all the society must be involved, because we find ourselves in front of a critical moment, that not only threatens our integration to the European Unison, but the most important, it threatens our lives and the well functioning of pour state, because it questions the security and the wellbeing of Albanian citizens. To reduce this high level of insecurity it will be necessary to have perseverance and common political will, society pressure, new reforms built by individuals that have the great will and the right motivation to no stop in front of anything, with the only aim of implementing these reforms and the creation of a high level of security.

\section{Bibliography}

[1] Ayoob, Muhammed. (1995). The third world Security Predicament. Boulder: Lynne Rienner.

[2] Bashkurti, Lisen. (2008). Krizat Ndërkombëtare. Mirgeeralb:Tiranë.

[3] Bashkëpunimi Rajonal për Zhvillimin dhe Integrimin Europian. (2007). Me mbështetjen e fondacionit Soros, East Program- Partnership Beyond Borders. AllS. Beograd, Podgoricë, Prishtinë Sarajevë, Shkup, Tiranë, Zagrep.

[4] Poda, Zamir. Krimi i organizuar transnacional. Morava: Tiranë.

[5] Strategjia Ndërsektoriale e Luftës kundër Krimit të Organizuar, Trafiqeve dhe Terrorizmit (August 2008). www.google.com/search?q=strategiia+ndersektoriale+e+luftes+kunder+krimit+te+organizuar\&rlz=1C1CHMO enAL483AL483\&oq=strategjia+ndersektoria\&aqs=chrome.0.69i59j69i57j014.74 (Accessed on 10 April 2014). 